\title{
Articles
}

\section{"Just Business" - Is the Current Regulatory Framework an Adequate Solution to Human Rights Abuses by Transnational Corporations?}

\author{
By Benny Santoso*
}

\begin{abstract}
Parallel to exponential proliferation and ever-increasing allegations of human rights violations by transnational corporations, the sparks produced by the friction between the normatively distinct disciplines of business and human rights have invited scrutiny across the media, academia, and industries alike. Given the fact that regulatory capacities of home and host states have evidenced an inability to keep pace with the developments, concerted efforts at the international level are imperative. By constructing its own benchmark of adequacy with reference to regulatory instruments' underlying objectives, this Article explores whether the existing regulatory framework is adequate, with a particular focus on the UN Framework and UN Guiding Principles-currently the most robust regime yet. The Article's analysis centers on (1) the terminologies utilized, (2) the human rights due diligence mechanism, and (3) access to remedies requirements, to reveal their inherent inadequacy with the hope of warning against uncritical acceptance and to inform future developments.
\end{abstract}

\footnotetext{
* Benny Santoso is a Practice Trainee at Rajah \& Tann Singapore LLP (International Arbitration, Construction Projects); LL.B (Bristol). He can be reached at bs13449@bristol.ac.uk. I am grateful to Dr. Albert Sanchez Graells, Dr. Jule Mulder, and Mr. Darryl Ho Jun Han for their critical readings of this text. The errors that remain are purely my own. The phrase "Just Business" in the Article's title is inspired by John Ruggie's book of this title. See JoHn G. RUGGiE, JUSt Business: MUltinational Corporations AND HUMAN RightS (2013).
} 


\section{A. Introduction}

At the pinnacle of neo-liberal economic policies, ${ }^{1}$ many businesses took advantage of deregulations, liberalization, and privatization to metamorphose into today's transnational corporations ("TNC(s)"). ${ }^{2}$ Nevertheless, according to a study ${ }^{3}$ by the Special Representative of the United Nations (UN) Secretary-General on Human Rights and Transnational Corporations and other Business Enterprises ("SRSG"), while Fortune 500 companies recognize the importance of human rights in their operations as a matter of both legal compliance and good practice, ${ }^{4}$ empirical evidence reveals an unprecedented $70 \%$ increase (2008-2014) in businesses abusing human rights globally. ${ }^{5}$ High profile human rights allegations, ${ }^{6}$ in conjunction with widespread state failures, ${ }^{7}$ provide some context to TNCs' impunity for human rights violations, ${ }^{8}$ thereby reinforcing this issue's gravity. Have two decades of calls for concerted international action generated an adequate regulatory framework? This Article posits that even the most robust of the current plethora of regulatory instruments ${ }^{9}$ is inadequate ${ }^{10}$ for holding TNCs accountable for this abuse of the corporate form.

${ }^{1}$ Stuart Hall, The Neoliberal Revolution, Thatcher, Blair, Cameron-The Long March of Neoliberalism Continues, 25 CULT. STUD. 705, 710 (2011).

${ }^{2}$ Adopting the terminology used in the UN Norms.

${ }^{3}$ Rep. of the Special Representative of the Secretary-General on the Issue of Human Rights and Transnational Corporation and Other Business Enterprises, Human Rights Policies and Management Practices: Results from Questionnaire Surveys of Governments and Fortune Global 500 Firm, Human Rights Council, U.N. Doc. A/C/4/35/ADD.3 (Oct. 28, 2007).

${ }^{4}$ Michael Addo, The Reality of the United Nations Guiding Principles on Business and Human Rights, 14 HUM. RTS. L. REV. 133, 135 (2014).

${ }^{5}$ Marilyn Croser, Human Rights Violations Have Increased 70\% Since 2008 Globally, The Guardian (Sept. 9, 2014), http://www.theguardian.com/sustainable-business/2014/sep/09/human-rights-violations-increase-corporateresponsibility.

6 Jim Yardley, Garment Trade Wields Power in Bangladesh, N.Y. TIMES (July 24, 2013), http://www.nytimes.com/2013/07/25/world/asia/garment-trade-wields-power-in-bangladesh.html?_r=0.

7 Amnesty Int'l, Corporations-Corporate Accountability, Amnesty Int'l (Dec. 1, 2014), http://www.amnesty.org/en/what-we-do/corporate-accountability/.

${ }^{8}$ Verisk Maplecroft, 2016 Human Rights Dataset, Maplecroft (2016), http://maplecroft.com/themes//.

${ }^{9}$ See inter alia Corporate Codes, Civil Society Guidelines, OECD Guidelines, ILO Tripartite Declarations, and the UN Global Compact.

${ }^{10}$ Tara J. Melish \& Errol Meidinger, Protect, Respect, Remedy and Participate: 'New Governance' Lessons for the Ruggie Framework, in THE UN GUIDING PRINCIPLES ON BUSINESS RIGHTS FOUNDATIONS AND IMPLEMENTATIONS 303, 307 (Radu Mares ed., 2012). 


\section{B. Definition of Terms and Scope}

\section{Abuse of the Corporate Form}

Why does this Article regard human rights violations by corporations ${ }^{11}$ as an abuse of the corporate form? United Kingdom (UK) company law recognizes the doctrines of separate

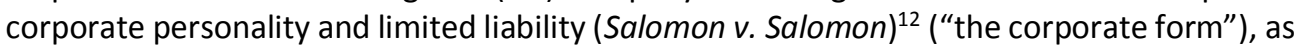
do most civil and common law systems. ${ }^{13}$ As these doctrines developed to protect investors $^{14}$ in an era when corporations could not acquire shares in other corporations without an express charter, ${ }^{15}$ this Article argues that extending them to corporate groups misappropriates the fiction of separation. ${ }^{16}$ While each jurisdiction has corporate veil piercing/lifting mechanisms (UK: Prest v. Petrodel), ${ }^{17}$ these rules are generally inapplicable in the context of human rights violations ${ }^{18}$ and are arguably ineffective when corporations "legitimately" establish subsidiaries to facilitate or manage investment, trade, and future legal risks. Consequentially, claims brought against subsidiaries are often undercompensated ${ }^{19}$ (e.g. Bhopal plant disaster). ${ }^{20}$ Therefore, when parent companies, exercising control-de facto or de jure-over subsidiaries' actions, facilitate, enable, benefit from, or negligently fail to prevent human rights violations by subsidiaries, the corporate form is abused to immunize parent companies from liability and responsibility. ${ }^{21}$

\footnotetext{
${ }^{11}$ Claudio Grossman \& Daniel D. Bradlow, Are We Being Propelled Towards a People-Centered Transnational Legal Order?, 9 AM. U. J. INT'L L. \& POL'Y 1, 8 (1993).

12 Salomon v. A Solomon \& Co. Ltd., [1896] UKHL 1.

${ }^{13}$ OXFoRd PRo Bono Publico, OBSTACLES TO JUSTICE AND REDRESS FOR VICTIMS OF CORPORATE HUMAN RIGHTS ABUSE 356 (2008), http://www2.law.ox.ac.uk/opbp/Oxford-Pro-Bono-Publico-submission-to-Ruggie-3-Nov-2008.pdf.

${ }^{14}$ See generally Cindy A. Schipani, Infiltration of Enterprise Theory into Environmental Jurisprudence, 22 J. CORP. L. 599 (1997).

${ }^{15}$ Phillip I. Blumberg, The Multinational Challenge to Corporation law: The Search for a New Corporate Personality 52 (1993).

${ }^{16}$ Surya Deva, Corporate Code of Conduct Bill 2000-Overcoming Hurdles in Enforcing Human Rights Obligations Against Overseas Corporate Hands of Local Corporations, 8 NeWC L. REv. 87, 100 (2004).

${ }^{17}$ Prest v. Petrodel Res. Ltd., [2013] UKSC 34.

${ }^{18} / d$.

19 LaWrence E. Mitchell, Corporate IRRESPonsibility: AmericA's NeWeSt EXPort $53-54$ (1st ed. 2001).

${ }^{20}$ See generally M.J. Peterson, Bhopal Plant Disaster-Situation Summary, in INTERNATIONAL DIMENSIONS OF ETHICS EduCATION IN SCIENCE AND ENGINEERING CASE StUdy SERIES (2009).

${ }^{21}$ See generally Henry Hansmann \& Reinier Kraakman, Toward Unlimited Shareholder Liability for Corporate Torts, 100 YALE L. J. 1879 (1991).
} 
Nevertheless, this abuse is aggravated in the context of TNCs, which possess features that enhance the means of evading liability available to TNCs. These include, inter alia, dissolving or reincorporating subsidiaries to become "legally invisible," 22 creating a global market for legal norm $\mathrm{s}^{23}$ by arranging operations to exploit laxer overseas standards, and utilizing forum non conveniens. ${ }^{24}$ These arise from the corporate form, which perceives each company separately and as a national of its state of incorporation and governed by its regulations. As such, this Article analyzes the adequacy of the existing regulatory framework with reference to $\mathrm{TNCS}^{25}$ which present the greatest challenge and demand an accordingly adequate solution. In addition, the complexity of constructing an all-encompassing definition of TNCs is well-recognized, ${ }^{26}$ but for analytical stringency, this Article's definition presents TNCs' relevant features in their strongest form: A corporation based in one country that owns, controls, or manages operations, either through subsidiaries or other entities, in another country and possesses a strong bargaining position relative to those countries.

\section{Regulatory Instruments Analyzed}

Traditionally, there have been legal doctrinal barriers to imposing direct human rights obligations on non-state actors through international law, ${ }^{27}$ and political barriers against using human rights instruments to police corporate excesses. ${ }^{28}$ Only recently has regulation focused directly on non-state actors, endeavoring to close the "governance gaps" 29 created by globalization and shortcomings of legal standards. These gaps gave TNCs immense economic and political power vis-à-vis emerging economies, ${ }^{30}$ which welcomed TNCs'

\footnotetext{
${ }^{22}$ Sagarika Chakraborty, Transnational Corporations, Other Business Enterprises And Human Rights: The Right Step Toward Corporate Social Responsibility?, Washington College of Law: Business Law Brief (2006), https://www.wcl.american.edu/blr/03/1chakraborty.pdf.

23 Jean-Phillippe Robé, Multinational Enterprises: The Constitution of a Pluralistic Legal Order, in GLOBAL LAW WITHOUT A STATE 45, 60-62 (Gunther Teubner ed., 1997).

${ }^{24}$ See generally Edward L. Barrett Jr., The Doctrine of Forum Non Conveniens, 35 CALlF. L. REv. 380 (1947).

${ }^{25}$ For example: uni-national corporations.

${ }^{26}$ See generally Cristina Baez, Michele Dearing, Margaret Delatour \& Christine Dixon, Multinational Enterprises and Human Rights, 8 U. MIAMI INT'L \& COMP. L. REV. 183 (2015).

${ }^{27}$ Andrew Clapham, Human Rights in the Private Sphere 61-63 (1996).

${ }^{28}$ See generally Sumithra Dhanarajan \& Claire Methven O'Brien, The Corporate Responsibility to Respect Human Rights: A Status Review, NUS LAW WORKING PAPER No. 2015/005 (2015).

${ }^{29}$ Björn Fasterling \& Geert Demuijnck, Human Rights in the Void? Due Diligence in the UN Guiding Principles on Business and Human Rights, 116 J. BUS. ETHICS 799, 808 (2013).

${ }^{30}$ See generally Justine Nolan, Refining the Rules of the Game: The Corporate Responsibility to Respect Human Rights, 30 UTRECHT J. OF INT'L \& EUR. L. 7 (2014).
} 
foreign investments, ${ }^{31}$ resulting in the aforementioned market for norms ${ }^{32}$ and creating a "permissive [human rights]-free environment," ${ }^{33}$ where "blameworthy acts... occur without adequate sanctions or reparations." ${ }^{34}$ For qualitative rather than quantitative analysis, ${ }^{35}$ this Article focuses on Professor John G. Ruggie's masterwork, ${ }^{36}$ Protect, Respect and Remedy: A Framework for Business and Human Rights ${ }^{37}$ ("Framework"), and Guiding Principles on Business and Human Rights ${ }^{38}$ ("UNGP").

Professor Ruggie was tasked ${ }^{39}$ with "identify[ing] and clarify[ing]" practicable human rights norms for states and corporations, implications of infringements, ${ }^{40}$ and resolve the "deontic confusion" 41 around the nature and scope of duties. After three years of consultation, the Framework received "unanimous welcome" by the United Nations Human Rights Council. ${ }^{42}$ Subsequently, the UNGP, containing thirty-one guiding principles ("GP(s)"), with commentaries, was published to operationalize the Framework, translating its conceptual

\footnotetext{
${ }^{31}$ Robé, supra note 23 , at $64-68$.

32 Jeanne M. Woods, A Human Rights Framework for Corporate Accountability, 17 ILSA J. OF INT'L \& COMP. L. 328, 333 (2012).

33 Olivier de Schutter, Extraterritorial Jurisdiction as a Tool for Improving the Human Rights Accountability of Transnational Corporation, Business and Human Rights Resource Centre (Dec. 1, 2006), http://businesshumanrights.org/en/pdf-extraterritorial-jurisdiction-as-a-tool-for-improving-the-human-rights-accountability-oftransnational-corporations.

${ }^{34}$ Rep. of the Office of the United Nations High Commissioner for Human Rights on the Impact of the Global Economic \& Financial Crises on the Realization of all Human Rights \& on Possible Actions to Alleviate it, Human Rights Council, U.N. Doc. A/C/13/38 (Feb. 18, 2010).

35 Peter Utting, Rethinking Business Regulation: From Self-Control to Social Control, TECHNOLOGY, BusINESS AND SOCIETY PRogramme PAPER No.15, 14-15 (2005).

${ }^{36}$ The Special Representative of the Secretary General of the United Nations (SRSG).

${ }^{37}$ Promotion and Protection of all Human Rights, Civil, Political, Economic, Social and Cultural Rights, Including the Rights to Development-Protect, Respect and Remedy: A Framework for Business and Human Rights, Report of the SRSG, Human Rights Council, U.N. Doc. A/C/8/5 (Apr. 7, 2008) [hereinafter Framework].

38 Guiding Principles on Business and Human Rights, Implementing the United Nations 'Protect, Respect and Remedy' Framework, Human Rights Council, U.N. Doc. A/HRC17/31 (Mar. 21, 2011) [hereinafter Guiding Principle(s)].

${ }^{39}$ Human Rights Council Res. 2005/69, U.N. Doc. E/CN.4/RES/2005/69 (Apr. 20, 2005).

${ }^{40}$ John G, Ruggie, Business and Human Rights: The Evolving International Agenda, 101 AM. J. OF INT'L L. 819, 826 (2007).

${ }^{41}$ Melish \& Meidinger, supra note 10 , at 306.

42 Human Rights Council Res. 8/7, U.N. Doc. A/C/RES/8/7 (June 18, 2008).
} 
responsibilities into practical results. ${ }^{43}$ As these represent an intricate synthesis of existing standards, legal and voluntary-and a truly global attempt to address widening governance gaps - they were well-received by stakeholders ${ }^{44}$-States, business associations, ${ }^{45}$ and civil society organizations. ${ }^{46}$ Indeed, they have become an "authoritative focal point" 47 in contemporary regulatory development, evidenced by incorporation into, inter alia, the OECD Guidelines, ${ }^{48}$ ISO 26000 Guidance, ${ }^{49}$ and further establishment of a United Nations Working Group ${ }^{50}$ to promote its dissemination and implementation. ${ }^{51}$

This overwhelming reception warrants critical analysis, as it risks promoting a "groupthink" mentality, 52 and unquestioning acceptance of its authority might prevent future improvement. If consensus and uptake, ${ }^{53}$ rather than fitness for purpose, indicate success, ${ }^{54}$

${ }^{43}$ U.N. Office of the High Commissioner for Human Rights, Council Holds Dialogue with Experts on Summary Executions, Independence of Judges and Lawyers, Transnational Corporations, Office of the High Commissioner for Human Rights (May 30 , 2011),

http://www.ohchr.org/en/NewsEvents/Pages/DisplayNews.aspx?NewsID=11082\&LangID=E.

${ }^{44}$ Robert McQuorcodale, Corporate Social Responsibility and International Human Rights Law, 87 J. Bus. ETHICs 385, 387 (2009).

${ }^{45}$ For example: International Council on Mining and Metals.

${ }^{46}$ For example: Amnesty International.

47 U.N. Human Rights Council, The UN "Protect, Respect and Remedy" Framework for Business and Human Rights, (2011), http://www.reports-and-materials.org/sites/default/files/reports-and-materials/Ruggie-protect-respectremedy-framework.pdf.

${ }^{48}$ OECD, OECD GUIDELINES FOR MULTINATIONAL ENTERPRISES (2011).

${ }^{49}$ ISO, GUIDANCE ON SOCIAL RESPONSIBILITY (2010), http://www.iso.org/obp/ui/\#iso:std:iso:26000:ed-1:v1:en.pdf.

${ }^{50}$ U.N. Office of the High Commissioner for Human Rights, Working Group on the Issue of Human Rights and Transnational Corporations and other Business Enterprises, Office of the High Commissioner for Human Rights (undated),

http://www.ohchr.org/EN/Issues/Business/Pages/WGHRandtransnationalcorporationsandotherbusiness.aspx.

${ }^{51}$ Human Rights Council Res. 17/4, U.N. Doc. A/C/RES/17/4 (June 16, 2011).

${ }^{52}$ See generally Jessica A. Pautz \& Donald A. Forrer, The Dynamics of Groupthink: The Cape Coral Experience, 2 J. OF INTERPROFESSIONAL EDUC. \& PRAC. 1 (2013).

${ }^{53}$ Surya Deva, Treating Human Rights Lightly: A Critique of the Consensus Rhetoric and the Language Employed by the Guiding Principles, in HUMAN RIGHTS OBLIGATIONS OF BUSINESS: BEYOND THE CORPORATE RESPONSIBILITY TO RESPECT? 78, 81 (Surya Deva \& David Bilchitz eds., 2013).

${ }^{54}$ Addo, supra note 4, at 146. 
TNCs may sign up ${ }^{55}$ to "bluewash" 56 their human rights failures, reenacting problems the United Nations Global Compact once faced..$^{57}$ This Article thus seeks to revive inquiry into whether these regulations are adequate to meaningfully change corporate behavior.

\section{Human Rights}

For terminological clarity, this Article defines "human rights" as fundamental moral rights, ${ }^{58}$ the "natural rights" 59 people possess qua rational and self-determined beings, 60 independent of voluntary action ${ }^{61}$ or institutional arrangements, ${ }^{62}$ and distinct from "corporate social responsibilities" of corporations characterized by voluntarism. ${ }^{63}$ Human rights are therefore generally absolute, and cannot be compromised in pursuit of other interest, for example, economic interests. In the language of obligations or duties, human rights equate to perfect obligations, and TNCs' responsibility to respect, elaborated below, is a universal perfect obligation not to violate human rights. Nevertheless, not all obligations the UNGP covers are perfect obligations, and this Article concedes that its argument is less persuasive with regard to duties besides perfect moral duties.

\section{Methodology}

\section{Foundational Presumption}

This Article first considers a fundamental question in the business-human rights clash: ${ }^{64}$ Why should TNCs be subjected to human rights obligations in the first place? This question has

\footnotetext{
55 Fletcher Forum, Business and Human Rights: Together at Last? A Conversation with John Ruggie, 35 THE FLETCHER FORUM OF WORLD AFFAIRS 117, 120 (2011).

${ }^{56}$ Andreas Rasche, A Necessary Supplement: What the United Nations Global Compact Is and Is Not, 48 Bus. \& Soc' $Y$ 511, 539 (2009).

57 U.N. Global Compact, The Ten Principles of the UN Global Compact, United Nations (undated), http://www.unglobalcompact.org/what-is-gc/mission/principles.

${ }^{58}$ Amartya Sen, Elements of a Theory of Human Rights, 32 PHILOS. PUB. Aff. 315, 319-21 (2004).

${ }^{59}$ H.L.A. Hart, Are There any Natural Rights?, 64 PHIL. REV. 171, 175-76 (1955).

${ }^{60}$ Eugene Schlossberger, A Holistic Approach to Rights: Affirmative Action, Reproductive Rights 157 (2007).

${ }^{61}$ Hart, supra note 59, at 177.

${ }^{62}$ Fasterling \& Demuijnck, supra note 29 , at 802.

${ }^{63}$ See generally Archie B. Carroll, A Three-dimensional Conceptual Model of Corporate Performance, 16 ACAD. MGMT. REV. 312 (1979).

${ }^{64}$ See generally Frank J. Garcia, The Global Market and Human Rights: Trading Away the Human Rights Principle, 25 BROOK. J. INT'L L. 51 (1999).
} 
its origins in the Berle-Dodd debate ${ }^{65}$ which contrasted shareholder and stakeholder models of the company-a dichotomy still debated in corporate governance scholarship today. Engagement with the normative question lies beyond this Article's scope, but the following analysis assumes a convincing justification for subjecting TNCs to human rights responsibilities.

\section{Benchmarks for Analysis}

In contemplating "adequacy," this Article measures the UNGP against its objectives, adopting a conceptual analysis of fitness for purpose, rather than an empirical evaluation of practical effectiveness. ${ }^{66}$ The underlying objective of the UNGP is to improve TNCs' human rights performance, and to ensure respect of their human rights obligations. Adequacy is thus a question of whether the UNGP can effectively realize this objective, ${ }^{67}$ assessed according to the degree to which it satisfies this Article's criteria of (1) deterrence and (2) enforcement.

Deterrence, inspired by criminal jurisprudence, ${ }^{68}$ requires that the norms impose clear, accurate, and substantive responsibilities prior to decision-making, as TNCs need conceptual clarity regarding what obligations they have, when they are in breach, and how to avoid this. Technically, the deterrent effect derives from sanctions giving these norms teeth, but these are considered under the enforcement criterion below. The above requirements are prerequisites for effective deterrence, as sanctions require clear formulation of protected rights.

Enforcement, including compensation, builds on jurisprudence that includes enforceability in the definition of legal rights. ${ }^{69}$ No instrument, however robust, can prevent all abuses, especially since some TNCs' actions defy enterprise rationality, ${ }^{70}$ thus necessitating effective responses. In defining this criterion, the insider perspective of the relevant parties is adopted.

For TNCs, effective enforcement means regulations must impose sanctions with reasonable certainty in a high percentage of cases, as adverse penalties are sine qua non for adequacy.

${ }^{65}$ E. Merrick Dodd, For Whom Are Corporate Managers Trustees?, 45 HARV. L. REV. 1145, 1155-62 (1932).

${ }^{66}$ See generally KATHARINA StRAsSMAIR, THE UN GUIDING PRINCIPLES ON BUSINESS AND HUMAN RIGHTS: THE IMPLEMENTATION ON THE INTERNATIONAL, REGIONAL, NATIONAL AND COMPANY LEVEL (2015).

${ }^{67}$ Françoise Tulkens, Human Rights, Rhetoric or Reality?, 9 EUR. REV. 125, 129 (2001).

68 See generally Anthony Ellis, A Deterrence Theory of Punishment, 53 PHIL. Q. 337 (2003).

${ }^{69}$ MORRIS GINSBERG, ON JUSTICE IN SOCIETY 247 (1971).

70 Arun Kumar \& Rachana Sharma, Principles Of Business Management 433 (2000). 
According to Hohfeld's analysis of legal rights, every right entails a correlative duty to act or to refrain from acting. ${ }^{71}$ Unless enforceable, rights are a "dead letter," and duties are merely voluntary obligations that may be fulfilled or ignored-ubis jus ibi remedium. ${ }^{72}$

Compensation, a sub-point of enforcement, is constructed from the victims' perspective. Building on Amnesty International's research into the denial of justice, ${ }^{73}$ theories of retributive justice, ${ }^{74}$ and zemiology, ${ }^{75}$ regulations must provide "effective compensation," both "in practice and in law," reparations" found in major international treaties. ${ }^{77}$ Effectiveness is further subdivided: Procedural effectiveness concerns the mechanisms for determining liability for breaches, ${ }^{78}$ requiring, inter alia, "equality of arms"79-affording parties equal opportunities to present their case ${ }^{80}$-the "right to be heard," ${ }^{81}$ and expeditious procedure. ${ }^{82}$ Conversely, substantive effectiveness concerns outcomes, converting "finding of facts and law" 83 to concrete results and granting "adequate... and appropriate" 84 relief for violations, entailing "a full and

\footnotetext{
${ }^{71}$ See generally Wesley N. Hohfeld, Fundamental Legal Conceptions as Applied in Judicial Reasoning, YALE LAW SCHOOL FACULTY SCHOLARSHIP SERIES, Paper 4378 (1917).

72 See generally Tracy A. Thomas, Ubis Jus, Ibi Remedium: The Fundamental Right to a Remedy, 41 SAN DIEGO L. REV. 1633 (2004).

${ }^{73}$ Amnesty International, Major new book calls for radical changes to stop corporate abuses, Amnesty Int'I UK (Mar. 11 2014) http://www.amnesty.org.uk/press-releases/major-new-book-calls-radical-changes-stop-corporateabuses.

74 D. Wood, Retributive and Corrective Justice, Criminal and Private law (2010), http://www.scandinavianlaw.se/pdf/48-33.pdf.

75 CARoline HANNAH McGill, Zemiology AND the dARK SIDE OF GLOBALISATION: THE CASE OF NAIVASHA'S CUT-FLOWER INDUSTRY (2012), http://eprints.lincoln.ac.uk/16180/1/_ddat01_staffhome_bjones_Downloads_53-194-1-PB.pdf.

${ }^{76}$ Kudla v. Poland [2000] 35 All ER 198 at [156].

${ }^{77}$ For example, EC, UDHR, ICCPR.

${ }^{78}$ Z. v. United Kingdom, [2002] All ER 97 at [108].

79 International Covenant on Civil and Political Rights, Dec. 16, 1966, S. Treaty Doc. No. 95-20, 6 I.L.M. 368 (1967), 999 U.N.T.S. 171, Art. 14 [hereinafter ICCPR].

${ }^{80}$ Dombo Beheer B.V. v. The Netherlands [1993] 18 EHRR 213 at [33].

${ }^{81}$ Convention for the Protection of Human Rights and Fundamental Freedoms, Nov. 4, 1950, 213 U.N.T.S. 222, Art. 6 [hereinafter $E C H R$ ].

${ }^{82} / d$.

83 Dinah Shelton, The Jurisprudence of Human Rights Tribunals on Remedies for Human Rights Violations, in INT'L PROTECTION Of HUM. RTS. AND VICTIMS' RTS. 57, 59 (J.F. Flauss ed., 2009).
}

${ }^{84}$ G.A. Res. 60/147, at Principle 2(c) (Mar. 21, 2006) [hereinafter Reparation Principle]. 
effective reparation" 85 proportionate to harm, ${ }^{86}$ to restore the status quo ante, ${ }^{87}$ jurisprudence well-established in theories of reparations. ${ }^{88}$

\section{Limitations}

This Article recognizes that Ruggie's mandate 89 "was not to win an award for academic excellence but to produce tangible policy results," ${ }^{\prime 90}$ and to break the post-Norms stalemate. $^{91}$ Nevertheless, this Article focuses on conceptual analysis, unconstrained by limitations of policy-making. Hence, critiques of the process and Ruggie's "principled pragmatism" ${ }^{\prime 92}$ bypassing controversial issues, ${ }^{93}$ analyzed exhaustively elsewhere, ${ }^{94}$ will not hamper this analysis. While these findings may never realistically materialize in policy, their value lies in raising issues that inform, or persuade, policymakers in developing effective regulation.

\section{Analysis}

While the Framework's pillars are mutually reinforcing, as the first pillar (GPs 1-10) uncontroversially ${ }^{95}$ reiterates the obligations of states under international law, ${ }^{96}$ focus lies

\footnotetext{
$85 / d$. at Principle 18.

${ }^{86}$ Scordino v. Italy (No. 1), [2006] ECHR 276 at [93].

87 Shelton, supra note 83 , at 87.

88 See generally Lisa J. Laplante, Just Repair, 48 CORNELL INT'L L. J. 513 (2015).

89 John G. Ruggie, Opening Statement to United Nations Human Rights Council (2006), http://www.reports-andmaterials.org/sites/default/files/reports-and-materials/Ruggie-statement-to-UN-Human-Rights-Council-25-Sep2006.pdf.

${ }^{90}$ Florian Wettstein, Normativity, Ethics, and the UN Guiding Principles on Business and Human Rights: A Critical Assessment, 14 J. OF HUM. RTS. 162, 163 (2015).

91 Sub-Commission on the Promotion and Protection of Human Rights, Norms on the Responsibilities of Transnational Corporations and Other Business Enterprises with Regard to Human Rights, U.N. Doc. E/CN.4/Sub.2/2003/12/Rev.2 (Aug. 26, 2003) [hereinafter UN Norms].

${ }^{92}$ Fasterling \& Demuijnck, supra note 29 , at 881.

${ }^{93}$ Melish \& Meidinger, supra note 10 , at 308.

${ }^{94}$ Karin Buhmann, Navigating from 'Train Wreck' to Being 'Welcomed': Negotiation Strategies and Argumentative Patterns in the Development of the UN Framework, in HUMAN RIGHTS OBLIGATIONS OF BUSINESS-BEYOND THE CORPORATE RESPONSIBILITY TO RESPECT? 29, 29-56 (Surya Deva \& David Bilchitz eds., 2013).

${ }^{95}$ Simon Baughen, human Rights And Corporate Wrongs, Closing the Governance Gaps 256 (2015).

${ }^{96}$ CLAPHAM, supra note 27 , at 61-63.
} 
on the latter two, concerning corporations' human rights responsibilities (GPs 11-24) and victims' access to remedies (GPs 25-31) respectively, with specific GPs that engage this Article's adequacy criteria being analyzed.

\section{Terminologies Utilized}

Adherence to discourse's unique language ${ }^{97}$ is essential to properly dictate the nature and scope of the human rights obligations of those subject to regulation. Nevertheless, this analysis suggests Ruggie's pursuit of consensus has produced "weak language concerning human rights responsibilities of business," ${ }^{18}$ compromising adequacy.

\section{Responsibility vs. Duty}

Founded upon Ruggie's conception of "differentiated but complementary responsibilities," "99 GP 11 distinguishes TNCs' human rights obligations from those of the States' obligations. TNCs have a "responsibility to respect,"100 likely derived from the principle sic utere tuo ut alterum non leades, ${ }^{101}$ in contrast with GP $1,{ }^{102}$ the State's "duty to protect." Together with the use of "should" - rather than "must" - throughout the second pillar, GP 11 deliberately avoids implying that it imposes legal obligations on TNCs, ${ }^{103}$ reflecting the conventional division between the duties of state and non-state actors in international human rights law. ${ }^{104}$ Indeed, GP 11 's Commentary confirms it is "distinct from issues of legal liability and enforcement." ${ }^{105}$

\footnotetext{
97 Christiana Ochoa, Advancing the Language of Human Rights in a Global Economic Order: An Analysis of a Discourse, 23 B.C. THIRD WORLD L.J. 57, 59 (2003).

${ }^{98}$ Deva, supra note 53, at 91.

${ }^{99}$ Framework, supra note 37 , at paragraph 9.

${ }^{100}$ Guiding Principles, supra note 38 (emphasis added).

${ }^{101}$ Henry Shue, Basic Rights: Subsistence, AfFluence, ANd U.S. Foreign Policy 76 (2nd ed. 1980).

102 Guiding Principles, supra note 38, Principle 1.

${ }^{103}$ BAUGHEN, supra note 95, at 261.

${ }^{104}$ Astrid Sanders, The Impact of the 'Ruggie Framework' and the United Nations Guiding Principles on Business and Human Rights on Transnational Human Rights Litigation, LSE LAW, SOCIETY AND ECONOMY WORKING PAPERS 18/2014, 8 (2014), https://www.lse.ac.uk/collections/law/wps/WPS2014-18_Sanders.pdf (emphasis added).

${ }^{105}$ Guiding Principles, supra note 38, Commentary to Principle 11 (emphasis added).
} 
This duty/responsibility dichotomy parallels Kant's conception of perfect/imperfect obligations. ${ }^{106}$ Rights, for example, human rights, must possess peremptory force, ${ }^{107}$ and consist of perfect obligations that are clearly defined and owed to specific right-holders, ${ }^{108}$ and must be fulfilled to the "fullest extent." 109 Conversely, imperfect obligations are indeterminate, not owed to-and incapable of being claimed by-any specific right-holder, may be overridden, and only bind parties to act in benevolence. While Ruggie claims responsibility to respect possesses normative value, ${ }^{110}$ he conceptualizes TNCs' human rights obligations as arising only from the "[basic] expected conduct"111 that society has of businesses, grounded in the "social license" 112 needed to operate-an implicit agreement between society and TNCs. Nevertheless, if TNCs are only "encouraged, but not obliged"113 not to violate human rights, and society only has an expectation-not a claim-against them, non-violation of human rights moves from an absolute, "perfect duty of justice"114 to an imperfect obligation, analogous to Corporate Social Responsibility ("CSR"). Deterrence is therefore compromised, as GP 11 fails to impose clear, unconditional human rights obligations on TNCs, thereby merely perpetuating the status quo. ${ }^{115}$

Furthermore, no clarification on the nature/origin of the "social license," defined as "prevailing social norms,"116 was provided, and its current conception is too nebulous to

\footnotetext{
${ }^{106}$ See generally Immanuel Kant, Fundamental Principle of the Metaphysics of Morals, in ETHICS: THE CLASSIC READINGS 166 (David E. Cooper ed., 1998).

107 Joel Feinberg, Social Philosophy 58-59 (1973).

${ }^{108}$ Allen Buchanan, Perfecting imperfect Duties: Collective Action to Create Moral Obligations, 6 Bus. ETHICS Q. 27, 28 (1996).

109 See generally IMMANUEL KANT, THE GROUNDWORK OF THE METAPHYSICS OF MORALS (1991).

110 Weil, Gotshal \& Manges llP Weil, Gotshal \& Manges LlP, Corporate Social Responsibility for Human Rights: COMMENTS ON THE UN SPECIAL REPRESENTATIVE'S REPORT ENTITLED “PROTECT, RESPECT AND REMEDY: A FRAMEWORK FOR BusineSS AND HUMAN RIGHTS" (2008), http://198.170.85.29/Weil-Gotshal-legal-commentary-on-Ruggie-report-22-May2008.pdf.

${ }^{111}$ Guiding Principles, supra note 38, at Principle 11.

112 Framework, supra note 37, at paragraph 54.

${ }^{113}$ Arvind Ganesan, UN Human Rights Council: Weak Stance on Business Standard-Global Rules Needed, Not Just Guidance, Human Rights Watch (June 16, 2011), http://www.hrw.org/news/2011/06/16/un-human-rights-councilweak-stance-business-standards.

${ }^{114}$ Wettstein, supra note 90, at 169.

${ }^{115}$ Susan A. Aaronson \& lan Higham, Re-righting Business: John Ruggie and the Struggle to Develop International Human Rights Standards for Transnational Firms, 35 HuM. RTS. Q. 333, 358 (2013).

116 See generally Neil Gunningham, Robert A. Kagan \& Dorothy Thornton, Social License and Environmental Protection: Why Businesses Go Beyond Compliance, 29 L. SOC. INQUIRER 308 (2004).
} 
provide coherent consensus on any particular issue. Societal expectations can only realistically generate rules in small, close-knit environments, ${ }^{117}$ and in the modern globalized economy rife with competing interests ${ }^{118}$ and value emphases, even TNCs committed to respecting human rights would be hard-pressed to identify what societal expectations are outside of the most obvious instances, since these can be spatially contingent: ${ }^{119}$ For example, China's tolerance of violations of freedom of expression. ${ }^{120}$ While guidance could be found in social practices, media, etc., social norms are also temporally contingent, ${ }^{121}$ constantly changing with societal views. People, society, and Norm Entrepreneurs ${ }^{122}$ act as the agents of such changes, ${ }^{123}$ which can occur rapidly ("Norm Bandwagons"), 124 before TNCs can respond. ${ }^{125}$ TNCs, and stakeholders, cannot therefore know with certainty the content of the human rights that require respect, since the UNGP omit an explicit catalogue of human rights-elaborated below-instead leaving identification to prevailing social norms. Without clarity and certainty, GP 11 cannot meaningfully inform TNCs' decisionmaking and prevent them from violating human rights, thereby compromising deterrence.

Lack of legal liability does not necessarily mean lack of sanctions, as the soft law consequences $^{126}$ prescribed by GP 11 could cause significant reputational damage to violating TNCs. ${ }^{127}$ Nevertheless, whether this punishment, administered through the "courts

\footnotetext{
117 H.L.A. HART, THE CONCEPT OF LAW 92 (1997).

118 Yadong Luo \& Rosalie L. Tung, International Expansion of Emerging Market Enterprises: A Springboard Perspective, 38 J INT'L BUS. STUD. 481, 497 (2007).

119 McQuorcodale, supra note 44, at 392.

120 Dan Levin, China Escalating Attack on Google, N.Y. TIMES (June 2, 2014), http://www.nytimes.com/2014/06/03/business/chinas-battle-against-google-heats-up.html?_r=0.

${ }^{121}$ Carloz Lopez, The 'Ruggie Process': From Legal Obligations to Corporate Social Responsibility? in HUMAN RIGHTS Obligations of Business-Beyond the CoRPorate ResPonsibility to ResPeCt? 58, 67 (Surya Deva \& David Bilchitz eds., 2013).

122 Cass R. Sunstein, Social Norms and Social Rules, 96 ColuM. L. ReV. 912, 913 (1996).

123 Patricia Illingworth, Global Need-Rethinking Business Norms, in THE BusinesS AND HUMAN RIGHTS LANDSCAPE: MOVING ForWARD, LOOKING BACK 175, 177 (Jena Martin \& Karen E. Bravo eds., 2015).

${ }^{124}$ Sunstein, supra note 122 , at 914.

125 Michael Addo \& Jena Martin, The Evolving Business and Society Landscape: Can Human Rights Make a Difference?, in THE BusinesS AND HUMAN RIghts LANDSCAPE: MOVING FoRWARD, LOOKING BACK 348, 348-49 (Jena Martin \& Karen E. Bravo eds., 2015).

${ }^{126}$ Anthony D'Amato, Softness in International Law: A Self-Serving Quest for New Legal Materials: A Reply to Jean d'Aspremont, 20 EUR. J. INT'L L. 897, 899 (2009).

${ }^{127}$ Chikako Oka, Accounting for the Gaps in Labour Standard Compliance: The Role of Reputation-conscious Buyers in the Cambodian Garment Industry, 22 EUR. J. DEV. RES. 59, 78 (2010).
} 
of public opinion" Ruggie adverts to, ${ }^{128}$ is consistent and certain enough to satisfy enforcement remains questionable: Who could realistically be expected to hold TNCs accountable and which rights or norms would they be held accountable to? With expectations of employees, communities, consumers, civil society, and investors comprising the standard by which TNCs are judged, can these distinct groups be expected to apply the same criteria? Furthermore, their assessments of TNCs' activities are subject to significant information asymmetries, compounded by the questionable credibility and accuracy of corporate reporting. ${ }^{129}$ According to the enforcement criterion, a system like the UNGP necessarily requires an effective theory of compliance. Without explicit mechanisms ${ }^{130}$ for obtaining relevant information and communicating it to the "judges,"131 the UNGP blindly trusts market forces (e.g. consumer awareness) to sanction human rights violations, ${ }^{132}$ which is unsatisfactory for enforcement, as this mechanism cannot impose sanctions with the consistency and certainty this Article requires.

\section{Protect vs. Respect}

The use of "protect" and "respect" likewise warrants scrutiny. The UNGP clarifies "respect" as: "[Doing] no harm"133 and "[avoiding] causing or contributing" 134 to human rights impacts. Commentators have interpreted this as negative responsibility, ${ }_{1}^{135}$ not encompassing "fulfilment or promotion" 136 of human rights, in contrast with states' positive responsibilities to protect human rights. Nevertheless, the conceptual accuracy and internal consistency of this dichotomy is suspect, and this has ramifications for GP11's adequacy. First, while some are indeed negative rights, requiring TNCs to refrain from certain acts-for example, Article

\footnotetext{
${ }^{128}$ Framework, supra note 37, at 16.

${ }^{129}$ Sally Wheeler, Global production, CSR and Human Rights: The Courts of Public Opinion and the Social Licence to Operate, THE INT'L J. OF HUM. RTS. 757, 769 (2015); See infra Part D.II.

${ }^{130}$ Ganesan, supra note 113.

${ }^{131}$ Wheeler, supra note 129 , at 770.

132 Richard M. Locke, The Promise AND Limits of Private PoWer 157 (2013).

${ }^{133}$ Framework, supra note 37, at paragraph 24.

${ }^{134}$ Guiding Principles, supra note 38, at Principle 13.

135 Florian Wettstein, CSR and the Debate on Business and Human Rights: Bridging the Great Divide, 22 BUS. ETHICS Q. 739, 753-55 (2012)

136 Business \& HUMAN Rights INITIATIVE, HOW to Do BUSinESS With RESPECT FOR HUMAN RIGHTS: A GUIDANCE TOOL FOR COMPANIES 45 (2010).
} 
5 of the UDHR prohibiting torture- ${ }^{137}$ this dichotomy becomes "tenuous and murky" ${ }^{138}$ when considering socio-economic rights, which contain positive rights that are as integral to the UNGP as civil and political rights. For example, what does Article 7 of the ICESCR, "right to a safe workplace," ${ }^{139}$ entail? TNCs cannot simply refrain from imposing dangerous working conditions. Respect must entail "doing something that provides some good or material as required by the right, ${ }^{140}$ for example, positively providing safe conditions ${ }^{141}$ Second, this dichotomy contradicts other sections of the UNGP, notably Pillar III, ${ }^{142}$ where Ruggie considers that a "grievance mechanism is part of the corporate responsibility to respect."143 How is the positive action of developing grievance mechanisms consistent with Ruggie's conception that respect merely entails negative obligation? Furthermore, if "social license" is the normative basis for TNCs' responsibility to respect, could societies potentially expect them to bear positive responsibilities, such as in regions where businesses are expected to contribute to positive realization of rights, for example, alleviating poverty? ${ }^{144}$

Given these issues, TNCs clearly must bear both negative and positive responsibility. Using "respect" to artificially distinguish the responsibilities of states and TNCs obfuscates the true scope of their duties, especially when these spheres are blurring together morally ${ }^{145}$ and legally, ${ }^{146}$ compromising deterrence. If TNCs view positive human rights responsibilities as state-exclusive, such interests are necessarily excluded from TNCs' decision-making, ${ }^{147}$ and the UNGP cannot deter TNCs from infringing them.

\footnotetext{
${ }^{137}$ G.A. Res. 217 (III) A, Universal Declaration of Human Rights, U.N. Doc. A/810 at 71 (1948), Art. 5 [hereinafter $U D H R]$.

138 Justine Nolan \& Luke Taylor, Corporate Responsibility for Economic, Social and Cultural Rights: Rights in Search of a Remedy?, 87 J. BUS. ETHICS 433, 443 (2009).

139 International Covenant on Economic, Social and Cultural Rights, Dec. 16, 1966, S. Treaty Doc. No. 95-19, 6 I.L.M. 360 (1967), 993 U.N.T.S. 3, Art. 7 [hereinafter ICESCR].

${ }^{140}$ SHUE, supra note 101 , at 62.

${ }^{141}$ G.C. Brenkert, Business, Respect, and Human Rights The Third Pillar: Remedies, Reparations, and the Ruggie Principles, in THe BusinesS AND HUMAN RIGHTS LANDSCAPE: Moving ForWARD, LOOKING BACK 154 (J. Martin \& K.E. Bravo eds., Cambridge University Press 2015).

${ }^{142}$ See infra Part D.III.

${ }^{143}$ Framework, supra note 37, at 24.

144 Illingworth, supra note 123 , at 189.

${ }^{145}$ Wettstein, supra note 90, at 172.

${ }^{146}$ Nolan \& Taylor, supra note 139 , at $438-39$

${ }^{147}$ Deva, supra note 53, at 95-6.
} 


\section{Scope of Human Rights}

GP 12 compounds this ambiguity by providing that TNCs have the responsibility to guarantee minimum standards of human rights, defined as those "expressed in the International Bill of Human Rights"148 and "International Labour Organization's Declaration on Fundamental Principles and Rights at Work,"149 without distinguishing between different categories of rights. Ruggie justified this scope with reference to Business and Human Rights Resource Centre reports, ${ }^{150}$ concluding that "there are few...internationally recognized rights business cannot impact," and a definitive, comprehensive set of standards ( $n . b$. UN Norms) would be inappropriate. ${ }^{151}$ Nevertheless, lack of clarity as to how extensive TNCs' responsibilities are with regards to particular rights is a well-known conceptual obstacle, ${ }^{152}$ because a requirement to respect "all of them" cannot meaningfully guide TNCs. ${ }^{153}$ The "omission of a catalogue [applicable] to companies" 154 is problematic, as the instruments cited are statefocused. ${ }^{155}$ Consider Article 12 of the ICESCR-the right to enjoyment of the highest attainable standard of physical and mental health. ${ }^{156}$ How extensive is TNCs' responsibility regarding this right? Must TNCs provide four days' rest per week for pristine mental health? The complexity of such questions compromises deterrence, as over-referencing statecentric human rights $^{157}$ causes inherent difficulties in transplantation, ${ }^{158}$ which would "neither be easy nor free from conceptual problems," requiring interpretation of abstract standards into quantifiable measuring tools and real-world deliverables that TNCs are

\footnotetext{
${ }^{148}$ Constituted by the UDHR, ICCPR, and ICESCR (emphasis added).

${ }^{149}$ Guiding Principles, supra note 38, at Principle 12 (emphasis added).

${ }^{150}$ Framework, supra note 37, at paragraph 52.

151 John G. Ruggie, Interim Report of the Special Representative of the Secretary-General on the Issue of Human Rights and Transnational Corporations and Other Business Enterprises, U.N. Doc. E/CN.4/2006/9, paragraph 55 (Feb. 22, 2006).

152 Brenkert, supra note 142 , at 146.

153 Roy Sullivan \& Nicolas Hachez, Human Rights Norms for Business: The Missing Piece of the Ruggie Jigsaw-The Case of Institutional Investors, in THE UN GUIDING PRINCIPLES ON BUSINESS RIGHTS FOUNDATIONS AND IMPLEMENTATIONS 217 , 230 (Radu Mares ed., 2012).

154 Surya Deva, Guiding Principles on Business and Human Rights: Implications for Companies, 9 EUR. COMPANY L. 101, 108-9 (2012).

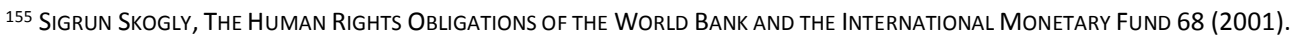

${ }^{156}$ ICESCR, supra note 140, Art. 12.

157 Surya DeVa, Regulating Corporate human Rights Violations-Humanizing Business 116 (2013).

158 Michael Goodhart, Human Rights and Non-State Actors: Theoretical Puzzles, in NON-STATE ACTORS IN THE HUMAN RIGHTS UNIVERSE 23, 34-35 (George J. Andreopoulos, Zehra F. Kabasakal Arat \& Peter Juviler eds., 2006).
} 
accustomed to. ${ }^{159}$ Effective deterrence would require responsibilities ${ }^{160}$ which are "easily translated into a compliance/non-compliance assessment framework." ${ }^{\prime 61}$ GP 12 is thus inadequate, as it "swamps rather than clarifies," and whether TNCs are willing or able to respect rights with indeterminate content is doubtful.

\section{Due Diligence Mechanism}

"Responsibility to respect" is discharged ${ }^{162}$ by TNCs through a management, governance, and communication process, ${ }^{163}$ constituting (1) a human rights policy commitment (GPs 1516); ${ }^{164}(2)$ ongoing human rights due diligence to identify, monitor, mitigate, and account for human rights impacts (GPs 17-18); ${ }^{165} 166$ and (3) remediation (GP 22). ${ }^{167}$ Analysis centers on due diligence, as it is central to the UNGP, 168 imposes the most onerous obligation on TNCs, effectively governs the scope of a TNC's human rights obligation, determines TNCs' response to human rights issues, and forms the basis for remediation.

Conceptually, due diligence possesses great potential to satisfy deterrence, since proper execution requires TNCs to stringently assess their human rights footprint. While due diligence was originally recommended by the International Commission of Jurists vis-à-vis states' duties, ${ }^{169}$ it is also standard industry practice for TNCs. ${ }^{170}$ Ruggie recognized that this

\footnotetext{
${ }^{159}$ Addo \& Martin, supra note 125 , at 381.

${ }^{160}$ See infra Part C. II.

${ }^{161}$ Sullivan \& Hachez, supra note 154, at 230.

162 Larry Catá Backer, From Institutional Misalignments to Socially Sustainable Governance: The Guiding Principles for the Implementation of the United Nation's 'Protect, Respect and Remedy' and the Construction of Inter-systemic Global Governance, PAC. MCGEORGE GLOBAL BUS. \& DEV. L. J. 102, 202 (2011).

${ }^{163}$ Fasterling \& Demuijnck, supra note 29, at 801.

${ }^{164}$ See generally Guiding Principles, supra note 38.

$165 / d$.

${ }^{166} / d$. at Principle 17.

$167 / d$. at Principle 22.

168 Backer, supra note 163, at 202.

${ }^{169}$ See generally INTERNATIONAL COMMISSION OF JURISTS, CORPORATE ACCOUNTABILITY, INTERNATIONAL HUMAN RIGHTS LAW AND THE UNITED NATIONS (2005).

170 Jeffrey S. Perry \& Thomas J. Herd, Mergers and Acquisitions: Reducing M\&A Risk through Improved Due Diligence, 32 StRATEGY \& LeADERSHIP 12, 15 (2012).
} 
broad rhetorical appeal ${ }^{171}$ and familiarity ${ }^{172}$ would ease its integration into management mindsets. ${ }^{173}$ Furthermore, by transforming TNCs' relationship with human rights from "naming and shaming" by external actors post-violation, to "knowing and showing,"174 due diligence changes managerial attitudes, thereby embedding human rights issues within routine decision-making processes. TNCs can thus engage in proactive prevention of human rights violations rather than retrospective reactions to claims. ${ }^{175}$ Prima facie, therefore, due diligence satisfies deterrence-prevention is better than cure, after all. Nevertheless, certain flaws in the UNGP's conception of due diligence result in disappointing shortfalls in discharging the "responsibility to respect." Unlike other instruments ${ }^{176}$ which have imposed due diligence responsibilities ${ }^{177}$ on TNCS, the UNGP lack precise expectations of human rights due diligence, particularly in four significant areas.

\section{Concept and Execution}

TNCs' familiarity with the due diligence concept creates the risk that inappropriate practices are retained, treating existing models of corporate monitoring due diligence as perfectly translatable to human rights. This Article clarifies that due diligence is fundamentally different in each context: The former relates to TNCs protecting themselves against economic risks, the latter to protecting rights of others. TNCs conducting human rights due diligence might thus apply the inappropriate company law duty of care, balancing directors' entrepreneurial freedom against shareholders' interests, whereas the more onerous human rights duty of care is not linked to financial success, but owed to people outside the company. ${ }^{178}$ Even worse, GP 18 conceptualizes human rights violations as "risks" to TNCs,

\footnotetext{
171 JONATHAN BONNITCHA \& ROBERT MCQUORCODALE, IS THE CONCEPT OF 'DUE DILIGENCE' IN THE GUIDING PRINCIPLES COHERENT? (2013), http://papers.ssrn.com/sol3/papers.cfm?abstract_id=2210457.

172 McQuorcodale, supra note 44, at 391.

173 Wheeler, supra note 129 , at 763.

${ }^{174}$ Christina Hill \& Serena Lillywhite, The United Nations 'Protect, Respect and Remedy' Framework: Six Years On and What Impact Has it Had?, 2 THE EXTRACTIVE INDUSTRIES \& Soc'y 4, 5-6 (2015).

175 Business and Human Rights: Further Steps Toward the Operationalization of the 'Protect, Respect and Remedy' Framework, Human Rights Council, U.N. Doc. A/HRSC/14/27, 16 (Apr. 9, 2010).

176 J.J. Eluyode, The Notion of Collective Human Rights and Corporate Social Responsibility: Issues and Trends in International Law, 24 INT'L COMPANY \& COM. L. Rev. 209, 214 (2013).

177 James Anaya, Extractive Industries and Indigenous Peoples-Report of the Special Rapporteur on the Rights of Indigenous Peoples, U.N. Doc. NA/HRC/24/41 (July 1, 2013).

178 Peter Muchlinski, Implementing the New UN Corporate Human Rights Framework, 22 Bus. ETHICS Q. 145, 161 (2012).
} 
implying they should be considered only if they pose business risks. ${ }^{179}$ The misconceptualization of due diligence as corporate risk assessment-compared with human rights protection ${ }^{180}$-opens the possibility for trade-offs between economic and human rights interests, treating violations as "business overheads" that may be outweighed by fiscal gains. Adequacy, therefore, hinges on individual TNCs' interpretation of due diligence, with adequacy diminishing the closer an interpretation comes to corporate risk management. This Article doubts, therefore, that due diligence can meaningfully deter TNCs from violating human rights, as it merely achieves internal self-validation of existing assessments and policies ${ }^{181}$ without meaningfully incorporating human rights interests into decision-making. Furthermore, if respecting human rights is contingent on benefiting the TNCs, it can be balanced against-and outweighed by-profit-maximization considerations in decisionmaking, weakening deterrence. ${ }^{182}$

\section{Transparency}

GP 21 establishes that TNCs "should" be prepared to provide "sufficient information" to external stakeholders to enable evaluation of how they address human rights impacts. This tenuous wording, combined with the UNGP's "soft" self-regulation, permits an unacceptable degree of latitude in disclosure, enabling TNCs to purport to undertake due diligence without disclosing documentation, ${ }^{183}$ thereby undermining its credibility. Likewise, GP 18, regarding the identification of adverse human rights impacts, encourages "meaningful consultation"184 with external stakeholders, but the extent of such engagement is entirely at TNCs' discretion. Stakeholders have no right to ensure the accountability of due diligence processes, ${ }^{185}$ and as TNCs can apply their own standards and define human rights that they "identify" free of independent scrutiny, the content of such human rights become so "elastic ... that they lose value as measures of performance." ${ }^{186}$

\footnotetext{
${ }^{179}$ L. J. Dhooge, Due Diligence as a Defense to Corporate Liability Pursuant to the Alien Tort Statute, 22 EMORY INT'L L. REV. 455, 496 (2008).

${ }^{180}$ Fasterling \& Demuijnck, supra note 29 , at 808-12.

181 James Harrison, Human Rights Measurement: Reflections on the Current Practice and Future Potential of Human Rights Impact Assessment, 3 J. OF HUM. RTS. PRAC. 162, 172 (2011).

182 Fasterling \& Demuijnck, supra note 29 , at 808-12.

${ }_{183}$ James Harrison, Establishing a Meaningful Human Rights Due Diligence Process For Corporations: Learning From Experience of Human Rights Impact Assessment, 31 IMPACT ASSESSMENT \& PROJECT APPRAISAL 107, 112-12 (2013).

${ }^{184} / d$. (emphasis added).

${ }^{185}$ Wheeler, supra note 129 , at 767.

186 James Harrison, Human Rights and Transnational Corporation: Establishing Meaningful International Obligations, in InTERnATIONAL EConomic LAW, GLobalization AND DeVeloping Countries 205, 214 (Julio Faundez \& Celine Tan eds., 2010).
} 
TNCs can therefore freely employ standards and methodologies inconsistent with deterrence, as illustrated by the following scenarios. Considering the high administrative costs "proper" due diligence involves, ${ }^{187}$ TNCs may favor form over substance, engaging in superficial "box-ticking" for reputational purposes rather than genuinely integrating human rights interests into decision-making, ${ }^{188}$ or strategically emphasize or obscure certain activities, ${ }^{189}$ a CSR tactic ${ }^{190}$ that regresses to the "anecdotal descriptions of isolated projects and philanthropic activity"191 that Ruggie intended to avoid. ${ }^{192}$ While TNCs may consider human rights issues in decision-making, without transparency and external verification, the clarity and substance of human rights obligations is lost. If TNCs intentionally or inadvertently overlook certain human rights obligations, ${ }^{193}$ due diligence has no deterrent impact whatsoever.

\section{Culpability}

If due diligence reveals adverse human rights impacts, GP 19 requires TNCs to take "appropriate action"194 depending on whether it "causes or contributes to an adverse impact," or where "impact is directly linked to its operations, products, or services by a business relationship." 195 The former applies to situations whereby parent companies are involved in subsidiaries' operations, analogous to direct tortuous liability (Chandler v. Cape Industries), ${ }^{196}$ while the latter covers situations where parent companies have no direct involvement. Notwithstanding the Commentary's contemplation of factors relevant to

\footnotetext{
${ }^{187}$ Fasterling \& Demuijnck, supra note 29 , at 808.

${ }^{188}$ Muchlinski, supra note 179, at 158.

${ }^{189}$ See generally John M. Conley \& Cynthia A. Williams, Engage, Embed and Embellish: Theory versus Practice in the Corporate Social Responsibility Movement, 31 J. CORP. L. 1 (2005).

190 Norman Jackson \& Pippa Carter, Organizational Chiaroscuro: Throwing Light on the Concept of Corporate Governance, 48 HUM. REL. 875, 886 (1995).

${ }^{191}$ Business and Human Rights: Mapping International Standards of Responsibility and Accountability for Corporate Acts, Human Rights Council, U.N. Doc. A/HRC/4/035 (Feb. 9, 2007).

192 Rep. of the Special Representative of the Secretary-General on the issue of human rights and transnational corporations and other business enterprises, John Ruggie-Business and Human Rights: Mapping International Standards of Responsibility and Accountability for Corporate Acts, Human Rights Council, U.N. Doc. A/HRSC/4/35 (Feb. 19, 2007).

${ }^{193}$ Harrison, supra note 184 , at 205-17.

194 Guiding Principles, supra note 38, at Principle 19.

${ }^{195} / d$.

${ }^{196}$ Chandler v. Cape Industries, [2012] EWCA Civ 525.
} 
determining appropriate action, the "causing or contributing" threshold delimits TNCs' responsibility to act, and Ruggie himself denied responsibility for TNCs where causality, whether direct or indirect, was absent. ${ }^{197}$ Nevertheless, as the large-scale institutional structures of TNCs can invisibly subsume the individual agency of actors further down the chain of causation, ${ }^{198}$ obscuring the ultimate causes of impacts, ${ }^{199}$ this apportionment of responsibility is perhaps inappropriate for correcting structural injustice. ${ }^{200}$ Enforcement is therefore compromised, as this conception allows TNCs to rely on remoteness to impacts as a defense against claims.

\section{External Monitoring}

GP 20 provides only for internal tracking of due diligence effectiveness, rather than independent external monitoring, compounding the issues considered above with unenforceability. Without access to sufficient information, ${ }^{201}$ or objective assessments of individual TNC's due diligence results, ${ }^{202}$ the courts of public opinion cannot distinguish between TNCs that are genuinely committed to respecting human rights and those merely paying them lip service, ${ }^{203}$ and, therefore, cannot appropriately sanction violators. Indeed, TNCs, knowing that the quality of due diligence cannot be questioned, may exploit this to "Ruggie-proof" their operations, ${ }^{204}$ employing due diligence processes to strategically and preemptively defend against claims, subverting its intended purpose ${ }^{205}$ and further compromising enforcement. Without the threat of sanctions, TNCs are unlikely to undertake stringent human rights due diligence that goes beyond voluntary disclosure or CSR reporting, for instance on subsidiaries/contractors involved in its operations, undermining due diligence's effectiveness. This has particular implications for GP 22, in determining whether claimants have "direct links" to the TNC for remediation.

\footnotetext{
197 Framework, supra note 37, at 20.

198 Onora Nell, Lifeboat Earth, 4 PHIL. PUB. AfF. 273, 286 (1975).

199 Samuel Scheffler, Boundaries and Allegiances: Problems of Justice and Responsibility in Liberal Thought 43-45 (2003).

200 IRIS MARION YOUNG, RESPONSIBILITY FOR JUSTICE, 102-107 (2013).

${ }^{201}$ See supra Part D.II.2.

202 Harrison, supra note 184, at 114.

${ }^{203}$ Fasterling \& Demuijnck, supra note 29, at 807.

${ }^{204}$ Id. at 805.

205 J.F. Sherman \& A. Lehr, Human Rights Due Diligence: Is IT ToO Risky?, 17-20 (2010), http://www.hks.harvard.edu/m-rcbg/CSRI/publications/workingpaper_55_shermanleHRs.pdf.
} 


\section{Access to Remedies}

The UNGP's third pillar (GPs 25-31) addresses the provision of effective remedies and grievance mechanisms ${ }^{206}$ for human rights violations at state and corporate levels. As the "Iynchpin of the entire accountability structure," ${ }^{207}$ it is crucial for victims. This Article considers the adequacy of the UNGP's conception of "procedural and substantive significance" ${ }^{208}$ against the compensation aspect outlined above. ${ }^{209}$

Procedurally speaking, Pillar III is relatively robust, establishing grievance mechanisms across multiple layers of institutional structure, potentially improving the UNGP's ability to satisfy the compensation criterion by increasing access to justice, as well as proactively preventing conflicts. ${ }^{210}$ The two-pronged approach-judicial and non-judicial-is particularly important, given the systems' distinct characteristics. Judicial mechanisms, specifically GP 25 , engage the power and legitimacy of public authority, providing certainty that remedies will be enforced. ${ }^{211}$ Nevertheless, this may vary across states, and the process is time- and moneyintensive ${ }^{212}$ hence, this remedy might be unrealistic or inappropriate for some victims. ${ }^{213}$ Justice systems also cannot realistically carry the burden of addressing all allegations. Alternatively, state-based non-judicial mechanisms such as GP 27 provided by an administrative or legislative branch of the government, for example, establishment of national human rights institutions via legislation or decree, can facilitate alternative dispute resolution, alleviating these limitations and complementing judicial mechanisms. Corporate and operational-level grievance mechanisms raised in GP 22 and reiterated in GP 29 provide further access to remedies, enabling smaller issues not amounting to violations to be identified and resolved directly before they become grave enough ${ }^{214}$ to warrant legal

\footnotetext{
${ }^{206}$ Guiding Principles, supra note 38, Commentary to Principle 25.

207 Jonathan Drimmer \& Lisa J. Laplante, The Third Pillar: Remedies, Reparations, and the Ruggie Principles, in THE BUSINESS AND HUMAN RIGHTS LANDSCAPE: Moving ForWARD, LOOKING BACK 316, 316-17 (Jena Martin \& Karen E. Bravo eds., 2015).

${ }^{208}$ Guiding Principles, supra note 38, at Commentary to Principle 25.

${ }^{209}$ See infra Part C. II.

210 John G. RUgGie, Presentation of Report to United Nations Human Rights Council (2009), http://www.reports-andmaterials.org/Ruggie-statement-to-UN-Human-Rights-Council-2-Jun-2009.pdf.

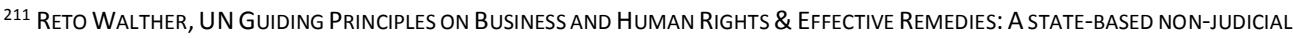
$\begin{array}{llll}\text { GRIEVANCE MECHANISM } & \text { FOR }\end{array}$ http://www.humanrights.ch/upload/pdf/140730_Walther_Klagemechanismus.pdf.

${ }^{212}$ Drimmer \& Laplante, supra note 208 , at 318.

${ }^{213}$ Guiding Principles, supra note 38, at Commentary to Principle 27.

${ }^{214}$ Caroline Rees, Piloting Principles for Effective Company-Stakeholder Grievance Mechanisms: A Report of Lessons Learned, in HARVARD KENNEDY SCHOOL CSR INITIATIVE 9 (2011).
} 
action. ${ }^{215}$ Simultaneously, they provide early detection for human rights issues in TNCs' operations, supporting ongoing due diligence efforts in identifying human rights impacts, achieving some deterrent effect. Furthermore, international and regional bodies and collaborative initiatives as part of non-judicial grievance mechanisms are considered, ${ }^{216}$ further expanding the remediation system.

The term "grievance," defined as "perceived injustice evoking an individual's or group's sense of entitlement," 217 is also meaningful. Commentary to GP 25 explains the expansive nature of this definition, including matters that might not attract remediation under existing international human rights law standards. ${ }^{218}$ This broader scope enhances the UNGP's procedural effectiveness, further enabling grievance mechanisms to address human rights issues at earlier stages.

Nevertheless, enhanced access notwithstanding, "quality control of remedies is essential for their success," 219 and the UNGP's benchmark for procedurally effective grievance mechanisms is inherently problematic. ${ }^{220}$ First, criteria for judicial effectiveness, inferred from the discussion of obstacles to remedy in GPs 25-26, identifies barriers preventing access to justice, such as forum non conveniens, separate corporate personality, enforcing host State judgements, and cost of litigation, ${ }^{221}$ the UNGP does not propose concrete policy recommendations to overcome these barriers. Instead, GP 26 only provides that States should, inter alia, take appropriate steps to ensure judicial mechanisms' effectiveness, and ensure such legal barriers do not obstruct access to remedies. ${ }^{222}$ Certainly, GP 26 is "potentially very important" 223 in prompting/reminding states to consider legal obstacles, but given the entrenchment of these doctrines, GP 26's weak language and lack of explicit guidance cannot compel states to resolve them, ${ }^{224}$ and such issues have persisted post-

\footnotetext{
${ }^{215}$ Drimmer \& Laplante, supra note 208, at 318-19.

${ }^{216}$ Guiding Principles, supra note 38, at Commentary to Principle 30.

217 Id. at Commentary to Principle 25.

${ }^{218}$ Drimmer \& Laplante, supra note 208 , at 320.

${ }^{219}$ Guiding Principles, supra note 38, at Commentary to Principle 31.

$220 / d$.

${ }^{221}$ Framework, supra note 37, at 22.

222 Deva, supra note 155 , at 113.

${ }^{223}$ See generally BAUGHeN, supra note 95.

${ }^{224}$ Deva, supra note 53, at 102.
} 
UNGP. ${ }^{225}$ Without properly addressing these obstacles, the UNGP cannot satisfy compensation.

Second, GP 31 details seven criteria for procedural effectiveness of non-judicial remedies, ${ }^{226}$ reinforcing Ruggie's emphasis on using non-judicial mechanisms to cover the judicial mechanisms' "governance gaps." 227 Nevertheless, per the UNHRC Expert Workshop, these criteria are not "comprehensive indicators," 228 and contain conceptual flaws, wherein nonsatisfaction does not necessarily entail ineffectiveness. Consider the criterion of "legitimacy,"229 which measures effectiveness by the trust stakeholders have in the system. In reality, complaints are often filed even without such trust because stakeholders are unaware of alternatives, particularly considering unresolved obstacles to judicial remedies. These criteria cannot, therefore, be taken at face value, and the degree to which they satisfy the compensation criterion is indeterminate. The European Business Network for Corporate Social Responsibility's tool for assessing effectiveness, containing GP 31's requirements, is currently being tested, so proper evaluation remains to be seen.

Pillar III's focus on procedural effectiveness also emphasizes its neglect of substantive effectiveness, which is considered only briefly in the Commentary to GP 25. As GP 25 is a foundational principle on states' duties, it may be extrapolated that substantive requirements for corporate remedies would be even less demanding. The Commentary's vagueness and lack of force is therefore problematic, as it only contemplates the substantive forms remedies may take, and considers that restoring the status quo ante is only, generally speaking, remediation's aim. By contrast, the UN Norms required TNCs to provide specific substantive remedies and made such remedies enforceable in national and international law, ${ }^{230}$ and the Reparation Principles ${ }^{231}$ clarified that remedies were obligations, not subject to the wrongdoer's discretion. The UNGP does precisely the opposite, construing access to remedies as a duty emanating from states' duty to protect and TNCs' responsibility to

\footnotetext{
225 GWynne Skinner, Robert McQuorcodale, Olivier De Schutter, The Third Pillar: Access to Judicial Remedies for HUMAN RIGHTS VIOLATIONS BY TRANSNATIONAL BUSINESS, 32-47, 77-84 (2013), http://corporate-responsibility.org/wpcontent/uploads/2014/02/The-Third-Pillar-FINAL.pdf.

${ }^{226}$ The seven criteria are that the remedies should be: Legitimate, accessible, predictable, equitable, transparent, rights-compatible, and a source of continuous learning, in the case of corporate mechanism, based on stakeholder engagement and dialogue.

227 WALTHER, supra note 212, at 27.

${ }^{228}$ Rep. from an Expert Workshop entitled "Business Impacts and Non-judicial Access to Remedy: Emerging Global Experience," Human Rights Council, U.N. Doc. A/HRC/26/25/Add.3, 10 (Apr. 25, 2014).

${ }^{229}$ Guiding Principles, supra note 38, at Principle 31(a).

230 UN Norms, supra note 91, at paragraph 18.

${ }^{231}$ See generally Reparation Principle, supra note 84.
} 
respect, ${ }^{232}$ downgrading remediation from a right in itself ${ }^{233}$ to a discretionary decision for states or TNCs, ${ }^{234}$ thereby significantly undermining compensation.

The lack of monitoring mechanisms to impose sanctions for non-implementation, or poor implementation, of grievance mechanisms, ${ }^{235}$ or failure to provide adequate remedy after grievance mechanisms are engaged ${ }^{236}$ further compromises compensation, as the procedural and substantive effectiveness of remedies becomes indeterminate.

\section{E. Conclusion: Going Forward}

The Framework and UNGP contain significant conceptual weaknesses, and are inadequate, by this Article's criteria, to address TNCs' abuse of the corporate form in violating human rights globally without repercussions. Nevertheless, the momentum, attention, and support ${ }^{237}$ that Ruggie's work brought back to the divisive debate ${ }^{238}$ surrounding the role of corporations in protecting human rights, ${ }^{239}$ especially since the "virtual halt" 240 after the UN Norms' failure, warrants recognition. Nevertheless, this Article's concerns regarding the UNGP's inadequacy, as well as calls for a "universally binding" 241 basis for human rights duties, have been shared by Ecuador and South Africa, whose proposals to UNHRC have produced a resolution ${ }^{242}$ establishing an Intergovernmental Working Group, kick-starting a negotiation process for a binding treaty on business and human rights. This Article's analysis

\footnotetext{
232 Deva, supra note 53, at 102.

${ }^{233}$ Drimmer \& Laplante, supra note 208, at 321.

${ }^{234}$ Deva, supra note 155 , at 116.

${ }^{235}$ Surya Deva and David Bilchitz, The Human Rights Obligations of Business: A Critical Framework for the Future, in HUMAN RIGHTS OBLIGATIONS OF BUSINESS-BEYOND THE CORPORATE RESPONSIBILITY TO RESPECT? 1, 16 (Surya Deva and David Bilchitz eds., 2013.

${ }^{236}$ WALTHER, supra note 212 , at 25.

${ }^{237}$ Wettstein, supra note 90, at 162.

${ }^{238}$ S. Jerbi, Business and Human Rights at the UN: What Might Happen Next?, 31 HUM. RTS. Q. 299, 301 (2009).

$239 / d$.

${ }^{240}$ Nicola Jägers, UN Guiding Principles On Business And Human Rights: Making Headway Towards Real Corporate Accountability?, 29 NETH. Q. OF HUM. RTS. 159, 160 (2011).

${ }^{241}$ Denis G. Arnold, Transnational Corporations and the Duty to Respect Basic Human Rights, 20 Bus. ETHICs Q 317, 389 (2010).

242 United Nations Human Rights Council Res. 26/9, U.N. Doc. A/HRC/RES/26/9 (July 15, 2014).
} 
may inform how the new treaty can work as an extension to the UNGP, ${ }^{243}$ as every regulatory instrument has conceptual and practical limitations on its adequacy stemming from its nature. Considering that this Resolution ${ }^{244}$ was passed by a slight majority vote, ${ }^{245}$ and recalling the problems the UN Norms faced in attempting to directly bind corporations, recognizing which inadequacies of the UNGP can be resolved internally by the Working Group is crucial, allowing the prospective treaty to focus on filling what governance gaps remain, and thereby increasing its chances of success. These instruments, along with other instruments at various institutional levels, can then complement one another's strengths and weaknesses in a gestalt integrated regulatory framework, ${ }^{246}$ thus maximizing their potential.

Reconciling business and human rights doctrines involves challenging orthodox doctrines, and there is no "single silver bullet" that can resolve this conflict. ${ }^{247}$ The Framework and UNGP's long-term (in)adequacy remains to be seen, since certain issues raised here could be resolved if the parties involved were fully committed in practical implementation. Nevertheless, critical scrutiny of the regulatory framework must continue, ${ }^{248}$ so as to promote constant evolution. This Article hopes to establish a case for some skepticism regarding claims of "progress," such that Ruggie's willingness to compromise human rights ideals for consensus does not set the precedent for future reforms.

\footnotetext{
243 Joe Zhang, Negotiations Kick Off on a Binding Treaty on Business and Human Rights, INVESTMENT TREATY NeWS (Nov. 26, 2015) http://www.iisd.org/itn/2015/11/26/negotiations-kick-off-on-a-binding-treaty-on-business-andhuman-rights/.

${ }^{244}$ See generally UN Human Rights Council, supra note 243.

${ }^{245}$ See generally Zhang, supra note 244.

${ }^{246}$ Deva, supra note 155 , at $176-231$.

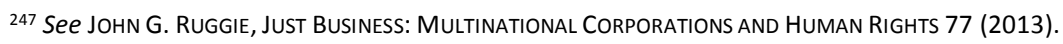

${ }^{248}$ Wettstein, supra note 90, at 163.
} 